The Management of Marine Regions: The North Pacific 


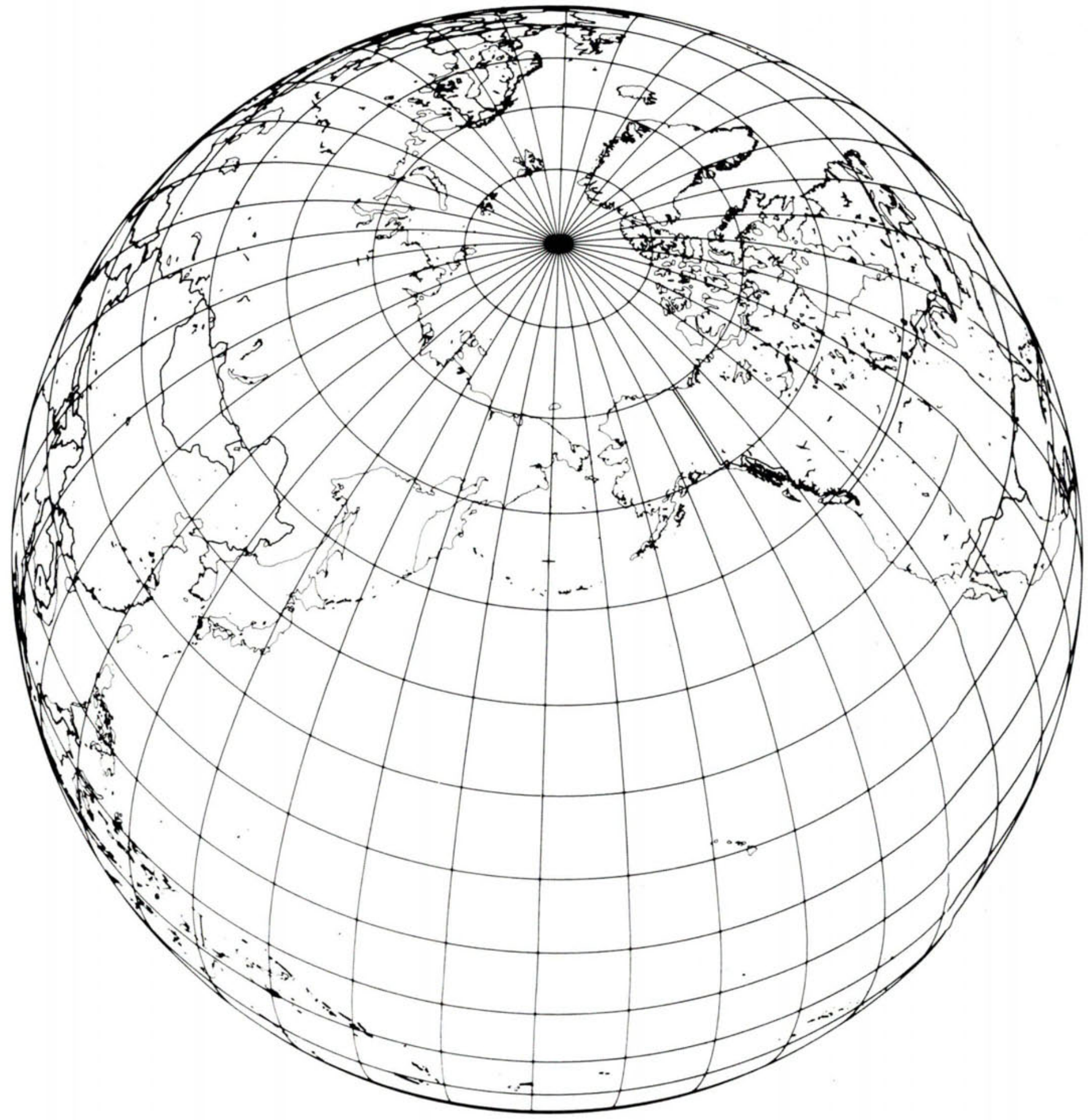




\section{The Management of}

Marine Regions: The North Pacific

An Analysis of Issues Relating to Fisheries, Marine Transportation, Marine Scientific Research, and Multiple Use

Conditions and Conflicts

EDWARD MILES, STEPHEN GIBBS, DAVID FLUHARTY, CHRISTINE DAWSON, AND DAVID TEETER

with

WILLIAM BURKE, WLODZIMIERZ KACZYNSKI, AND WARREN WOOSTER

University of California Press Berkeley Los ANGeles London 
UNIVERSITY OF CALIFORNIA PRESS

Berkeley and Los Angeles, California

UNIVERSITY OF CALIFORNIA PRESS. LTD.

London. England

COPYRIGHT (C) 1982 BY THE REGENTS OF THE UNIVERSITY OF CALIFORNIA

\section{Library of Congress Cataloging in Publication Data}

Main entry under title:

The Management of marine regions.

Includes bibliographical references and index.

I. Fishery management. International-North Pacific

Ocean. 2. Marine resources and state-North Pacific Ocean.

3. Shipping-North Pacific Ocean-Government policy.

4. Marine sciences-Research-North Pacific Ocean-

Government policy. 5. Fishery policy-North Pacific Ocean.

6. Maritime law-North Pacific Ocean. I. Miles, Edward L.

$\begin{array}{lll}\text { SH2 14.2.M36 } 333.91^{\prime} 64^{\prime} 091644 & 81-19657\end{array}$

ISBN $0-520-04458-4$

AACR 2

PRINTED IN THE UNITED STATES OF AMERICA 
For the late Donald L. McKernan, the Faculty, and Students of the Institute for Marine Studies, University of Washington 
